\title{
Ending hunger is possible - institutional change matters
}

\author{
Review by Marianna Siegmund-Schultze* \\ Berlin Institute of Technology (TU Berlin)
}

Review of Beginning to $\mathrm{E}$ nd $\mathrm{H}$ unger: Food and the $\mathrm{E}$ nvironment in Belo H orizonte, Brazil, and Beyond, by M. Jahi Chappell. (2018). Published by the University of California Press. Available as hardcover, paperback, and ebook; 272 pages. Publisher's website: https:/ / www.ucpress.edu/ book/ $9780520293090 /$ beginning-to-end-hunger

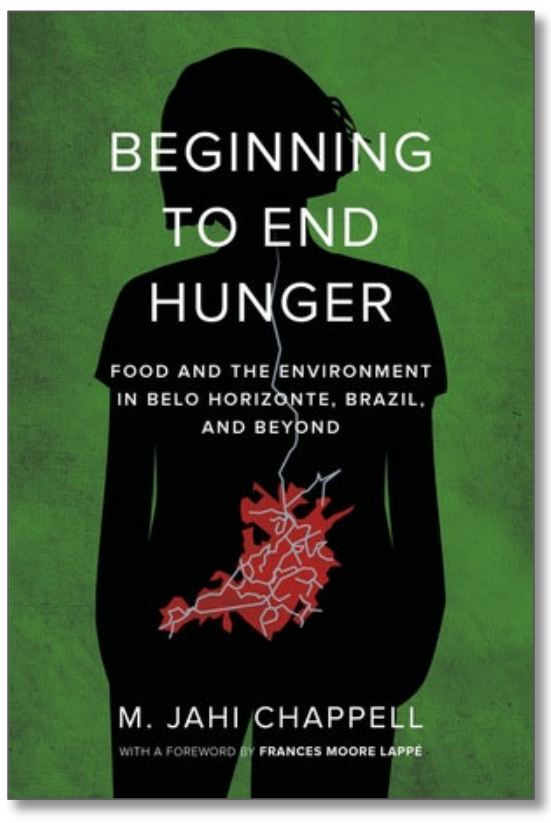

Submitted September 13, 2018 / Published online November 4, 2018

Citation: Siegmund-Schultze, M. (2018). Ending hunger is possible - institutional change matters [Book review]. Journal of A griculture, F ood Systems, and Community D evelopment, 8(3), 217-219. https:// doi.org/ 10.5304/ jafscd.2018.083.019

Copyright ( 2018 by the Author. Published by the Lyson Center for Civic Agriculture and Food Systems. Open access under CC BY license.

Jahi Chappell continuously begs the question: "Who benefits?" He shares his thoughts about hunger and our food systems in his book Beginning to $\mathrm{E}$ nd $\mathrm{H}$ unger: Food and the $\mathrm{E}$ nironment in Belo $\mathrm{H}$ orizonte, Brazil, and Beyond. In six chapters, he outlines his analytical background and tells the story about an extraordinary effort to end hunger in the city of

\footnotetext{
* Marianna Siegmund-Schultze, $\mathrm{PhD}$, is an agricultural scientist and systems thinker at the Berlin Institute of Technology (TU Berlin), Germany, working on the interfaces of socioeconomics, natural resources, and governance. She recently served as a visiting professor in Brazil, where she taught courses about environmental governance. Previously, she was the scientific manager of a collaborative research project on sustainable land management with a large team of Brazilian and $\mathrm{G}$ erman researchers. She can be reached at marianna.siegmund-schultze@gmx.de.
}

Belo Horizonte and its surrounding villages. The book is preceded by a foreword by Frances Moore Lappé, who encourages us to rethink common assumptions as part of the solution. In the introduction (chapter 1), Chappell introduces institutions and epistemology, and coins the terms Minority W orld (for instance, wealthier areas such as the U.S. and the E.U.- where relatively few people live) and M ajority W orld (where the majority of the world's population lives, in economies such as Brazil's). He reminds us to be careful when adopting food security indicators: do not take information out of context, but account for the multifaceted and intertwined nature of the subject. Then he shares a list of eight basic propositions about global food systems (although he unfortunately does not reveal how he arrived at 
these). The major message is: there is enough food in most places at most times, and perceived scarcity and unhealthy patterns are often a question of profitability and the institutions (the rules, norms and values) that govern societal behavior.

In chapter 2, Chappell revisits relevant theories and concepts of the field: (1) productivism, decline in food availability, and neo-productivism;

(2) hunger, entitlements, and food security; and (3) food justice and food sovereignty. Chappell laments that food security discourses are "often depoliticized, ahistorical, and at best agnostic regarding power inequalities" (p. 62). He advocates for us to analyze lines of rhetoric in order to understand the worldviews of their defenders. Most importantly, he directs, always ask "Why?" In this chapter, Chappell also introduces one of the frameworks he will use in the following chapters: the Five A's of Food Security (according to Cecilia Rocha). These are availability, accessibility, adequacy, acceptability, and agency.

In chapter 3, Chappell describes the rise, most productive times, and challenges of Belo Horizonte's Municipal Under-Secretariat of Food and Nutritional Security (with the Portuguese abbreviation of SMASAN). In a short time, it issued a large number of policies related to food security. Just to name a few: Popular restaurants (very cheap meals), ABC stores (20 to 25 consistently cheap basic items), School Meals, Consumer Education, Promotion of Community and School Orchards, and sales spaces for produce sold through "Straight from the Countryside" and Organic Fairs programs. Assessed along the Five A's, the implemented programs contributed to secure food availability from small farmers' local production. Accessibility was achieved, though with varying degrees of success. Acceptability and appropriateness of foods were widely met, while metrics for agency and a right-to-food agenda indicated the SMASAN approach still had some flaws. In particular, people hardly knew who was behind which program, and some people were free-riding and improved only their own circumstances.

An analysis of the food programs' metrics follows in chapter 4 . The multiple streams approach (MSA) of problems-policies-politics (following John Kingdon) was Chappell's method of choice. SMASAN's establishment profited from a policy window under a determined mayor (Patrus Ananias), who, together with a renowned scientist in food policy (Maria Regina Nabuco, SMASAN's first secretary), set up the new Under-Secretariat. Nabuco was apparently genius at leadership; she knew very well what was going on, how all the initiatives worked together, and what each member's role was. The process slowed down when the policy window closed and less-engaged leaders followed. Nevertheless, it inspired a continuation of the programs' spirit when Ananias later served as Federal Minister for Social D evelopment and Fight against Hunger with the famous Zero Hunger flagship program.

Chapter 5 is partly a remake of a published paper on the two-way interrelationship of food security and biodiversity. In it, Chappell reports some (known) challenges of data collection. He again highlights that "basic human rights- including agency and substantive democracy - are keys to a world without hunger" (p. 164). D eep institutional changes and embeddedness, i.e., the interpersonal ties among societal and governmental actors, are fundamental for the fair and effective implementation of policies.

Finally, Chappell applies the MSA to the U.S. food system, which I initially found to be a surprising approach to the conclusion. However, it turned out to be a useful presentation of how to use the theory as a practitioner. Policy windows are difficult to open intentionally. That is why it is extremely relevant to contribute to the convergence of potential solutions by repeating the subject in order to increase public awareness and the odds that the issue will become a matter of broader action. People who enable such synergies are desperately needed.

Chappell writes with passion and is keen on getting his message through. The book is easy to read, although some sections are a bit lengthy and at times repetitive. It is useful that he frequently provides evidence from interviews he conducted. Sometimes it made me a bit impatient, especially when it comes to names and kinship. This could be due to his presumed embeddedness- he conducted fieldwork repeatedly over several years, calls several cited persons his friends, and acknowledges 
a large number of people. Though it makes the reading laborious at times, this approach also displays his strong commitment to the topic and people he is writing about.

The book is valuable reading for all people interested in food security in the comprehensive sense that Chappell outlines in his book. I hope that the book will be translated into Portuguese so it can be easily read locally by those Chappell writes about. Reading about international attention to domestic policies can trigger pride and identification on the one hand. On the other hand, the analyses and lessons learned may spur further activities. Personally, I most enjoyed chapter 4, where Chappell provides insights into specific success factors for the productive years of SMASAN's pioneering approach to ending hunger. Eventually, he ends his book on the encouraging note that ending hunger is possible. 